\title{
Identification and antimicrobial susceptibility of bacteria isolated from corneal ulcers of dogs
}

\author{
[Identificação e susceptibilidade antimicrobiana de bactérias \\ isoladas de úlceras de córnea em cães] \\ M.R. Prado ${ }^{1}$; E.H.S. Brito ${ }^{1}$; M.D. Girão ${ }^{1}$; J.J.C. Sidrim ${ }^{2}$; M.F.G. Rocha ${ }^{1,2}$ \\ ${ }^{1}$ Aluna de pós-graduação - FMV-UECE, Fortaleza. \\ ${ }^{2}$ Faculdade de Medicina - UFC - Fortaleza, CE.
}

\begin{abstract}
A total of 22 clinical specimens were obtained from 19 dogs with corneal ulcer (16 unilateral and three bilateral) for isolation and antimicrobial susceptibility evaluation of the isolated bacteria. Bacterial growth was observed in $100 \%$ of the samples $(\mathrm{n}=22)$. Staphylococcus intermedius was the predominant species (35.5\%), followed by Corynebacterium xerosis (19.3\%). Gentamicin, ciprofloxacin, chloramphenicol and tobramycin had a high efficacy against all of the isolated bacteria. The results evidenced that $80.7 \%$ of the isolates were Gram positive cocci and Gram positive bacilli, and that those microorganisms were sensitive to gentamicin, ciprofloxacin, chloramphenicol and tobramycin.
\end{abstract}

Keywords: dog, corneal ulcer, bacteria

\section{RESUMO}

Utilizaram-se 22 amostras de material, obtidas de 19 cães com úlcera de córnea, sendo 16 unilaterais e três bilaterais, para isolamento e avaliação da susceptibilidade antimicrobiana das bactérias isoladas. Observou-se crescimento bacteriano em $100 \%$ das amostras $(\mathrm{n}=22)$. A espécie predominante foi Staphylococcus intermedius (35,5\%) seguido de Corynebacterium xerosis (19,3\%). Gentamicina, ciprofloxacina, cloranfenicol e tobramicina apresentaram alta eficácia contra todas as bactérias isoladas. Os resultados evidenciam que $80,7 \%$ dos isolados foram cocos e bacilos Gram positivos e que estes microrganismos foram sensíveis à gentamicina, ciprofloxacina, cloranfenicol e tobramicina.

Palavras-chave: cão, úlcera de córnea, bactéria

\section{INTRODUCTION}

Corneal ulcer is a common disease in domestic animals, especially dogs. Although the corneal ulcer usually has a traumatic origin, it may rapidly become contaminated with bacteria (Slatter, 2001). The corneal ulcer is characterized by a loss of corneal epithelium and activation of stromal fibroblasts, leading to swelling of the stroma, and migration of inflammatory cells, with a subsequently loss of corneal integrity and transparency (Suzuki et al., 2003). Once the ulcer is infected, the healing process is retarded and can lead to an endophthalmitis, or glaucoma (Gelatt, 2000). Therefore, treatment with antibiotics must be initiated when corneal ulcers are diagnosed.

Recebido em 23 de fevereiro de 2005

Aceito em 28 de julho de 2006

Endereço para correspondência (corresponding address)

Rua E, 22 - Esplanada Messejan

60872-140 - Fortaleza - CE

E-mail: lena@inteq.com.br 
For this purpose, an association of antibiotics should be used to improve their spectrum. Slatter (2001) and Gelatt (2000) recommended the use of ophthalmic preparations containing neomycin, bacitracin and polymyxin B. However, if a melting ulcer is present, gentamicin, tobramycin, ciprofloxacin and amikacin should be the antibiotics of choice (Slatter, 2001; Suzuki et al., 2003; Whitley and Gilger, 1999).

The antibiotic therapy is selected based on the culture and susceptibility of antimicrobial tests of the isolated bacteria (Moore et al., 1988). However, sometimes these tests are not performed, whether due to their cost or because the treatment must be initiated before their results. In these cases, the choice of the drug could be based on the incidence of pathogens at the location, and its probable sensitivity to the drug (Gelatt, 2000). Therefore, the aims of this study were to identify the microorganisms involved in corneal ulcers in dogs and their respective susceptibility to antimicrobials.

\section{MATERIAL AND METHODS}

The dogs included in this investigation were submitted to previous clinical and ophthalmic examinations, using a penlight, a direct ophthalmoscope and a slit-lamp. Corneal ulcers were detected by fluorescein stain (Fig. 1). This study included 19 dogs with unilateral or bilateral corneal ulcer. A total of 22 clinical specimens were obtained from 3 bilateral and 16 unilateral corneal ulcers, between October 2002 and February 2003. The samples were obtained in collaboration with six veterinary practices in the city of Fortaleza, Ceará. The age, breed, sex and clinical data of the animals were recorded and are listed in Table 1. Three dogs had already received antimicrobial treatment (two dogs were prescripted tobramycin three times daily and one dog chloramphenicol two times daily).

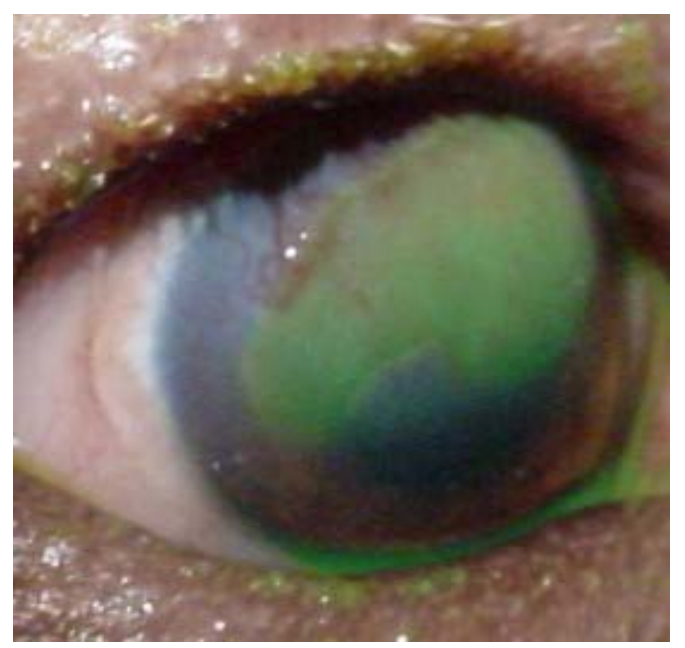

Figure 1. Eye of a Sharpei with entropion and corneal ulcer, evidenced by fluorescein stain.

Table 1. Ulcerative keratitis in dogs according to breed, sex, age, habitat, clinical data and affected eye

\begin{tabular}{lccccc}
\hline \multicolumn{1}{c}{ Breed } & Sex & Age (months) & Habitat & Clinical data & Affected eye \\
\hline Poodle (toy) & Male & 72 & Indoor & Renal failure & Left eye \\
Poodle (toy) & Female & 15 & Indoor & Healthy & Left eye \\
Poodle (toy) & Female & 28 & Indoor & Healthy & Right eye \\
Poodle (toy) & Male & 1 & Indoor & Healthy & Right eye \\
Pekinese & Male & 60 & Indoor & KCS & Left eye \\
Pekinese & Male & 120 & Indoor & KCS & Bilateral \\
Pekinese & Male & 132 & Indoor & KCS & Bilateral \\
Mixed breed & Female & 55 & Indoor & Healthy & Right eye \\
Mixed breed & Female & 74 & Indoor & KCS & Bilateral \\
Pinscher & Male & 29 & Indoor & Healthy & Left eye \\
Pinscher & Female & 11 & Indoor & Healthy & Right eye \\
English Cocker Spaniel & Female & 42 & Indoor & KCS & Left eye \\
German Shepherd & Male & 1 & Outdoor & Healthy & Left eye \\
York Shire Terrier & Male & 54 & Indoor & Dermatophytosis & Right eye \\
Sharpei & Male & 13 & Indoor & Entropion & Left eye \\
Boxer & Male & 8 & Outdoor & Demodicosis & Right eye \\
Schnauzer & Male & 108 & Indoor & Healthy & Right eye \\
English Bulldog & Male & 27 & Outdoor & Entropion & Right eye \\
Rottweiler & Female & 48 & Outdoor & Healthy & Right eye \\
\hline KCS k k & & & &
\end{tabular}


Clinical specimens were obtained from each corneal ulcer by corneal scraping after topical anesthesia with proparacaine $0.5 \%$. The samples were placed directly into brain-heart-infusion (BHI) broth and transported to a medical mycology specialized center.

The clinical specimens were incubated at $37^{\circ} \mathrm{C}$. After 24 hours the samples were subcultured on blood-agar, chocolate-agar and MacConkey agar and incubated at $37^{\circ} \mathrm{C}$ for 48 hours. The bloodagar plates were incubated in an atmosphere of $5 \% \quad \mathrm{CO}_{2}$. The clinical specimens were daily examined for evidencing of microbial growth. The plates not presenting microbial growth within the incubation period (24-48h) were considered negative. The isolates were then purified, Gram-stained and identified by morphological characteristics and the use of standard biochemical tests (Koneman et al., 2001).

Bacteria were tested for antimicrobial susceptibility using the Kirby-Bauer diskdiffusion method, according to Performance... (1999). The following antibiotics were tested for all isolates: gentamicin, chloramphenicol, trimethoprim plus sulfadiazine, erythromycin, tobramycin and ciprofloxacin.

\section{RESULTS}

Bacteria were recovered from all of the 22 samples from corneal ulcers. A single bacterial species was isolated in 14 specimens $(63.6 \%)$, while eight $(36.4 \%)$ samples presented two or three different microorganisms.

A total of 31 isolates were recovered, the predominant group being Gram-positive cocci $(51.7 \%)$, followed by Gram-positive bacilli (29\%) and Gram-negative bacilli (19.3\%). Staphylococcus spp. was the most frequently isolated genus $(45.2 \%)$, followed by Corynebacterium spp., which represented $22.5 \%$ of the isolates. The results for each species are seen in Table 2.

Table 2. Bacterial isolates from corneal ulcers, presenting the number and percentage of each bacterial species

\begin{tabular}{lcc}
\hline \multirow{2}{*}{ Organism } & \multicolumn{2}{c}{ Isolates } \\
\cline { 2 - 3 } & $\#$ & $\%$ \\
\hline Cocci Gram positive & 11 & 35.5 \\
$\quad$ S. intermedius & 2 & 6.5 \\
S. aureus & 1 & 3.2 \\
$\quad$ S. cohnii & 2 & 6.5 \\
$\quad$ Streptococcus viridans group & & \\
Bacilli Gram positive & 2 & 6.5 \\
$\quad$ Bacillus spp. & 6 & 19.3 \\
C. xerosis & 1 & 3.2 \\
C. afermentans & & \\
Bacilli Gram negative & 2 & 6.5 \\
$\quad$ Enterobacter cloacae & 1 & 3.2 \\
Klebsiella pneumoniae & 1 & 3.2 \\
$\quad$ Escherichia coli & 1 & 3.2 \\
Pseudomonas aeruginosa & 1 & 3.2 \\
$\quad$ Acinetobacter lwoffi & \\
\hline
\end{tabular}

Four antibiotics had high efficacy against the isolates: gentamicin (96.8\%), ciprofloxacin (96.8\%), chloramphenicol (93.5\%) and tobramycin (90.3\%). Trimethoprim plus sulfadiazine and erythromycin were effective only against $61.3 \%$ and $32.3 \%$ of the isolates, respectively. The results of susceptibility testing for each species are indicated in Table 3.

All animals received antimicrobial treatment (tobramycin, at least six times daily) associated with acetylcystein (20\% solution) or autologous serum (nine dogs). The dogs with entropion were submitted to surgery to correct the eyelid disorder and the five dogs with keratoconjunctivitis sicca received concomitant treatment with topical cyclosporine. Conjunctival flap was performed in eight dogs to prevent corneal perforation and to improve corneal healing. In all animals the ulcerative keratitis healed between one and four weeks of treatment with minimum scar formation. 


\section{DISCUSSION}

Salisbury et al. (1995) presented similar results of this study by studying dogs with keratoconjuntivitis sicca (KCS). They reported that $93 \%$ of the eyes presented bacterial growth. However, Gerding Jr. et al. (1988) recovered bacteria only from $66.2 \%$ of the samples from dogs with external eye diseases in the United States and only $6 \%$ of the positive specimens showed two or more microorganisms. These variations could be a result of the different sampling technique, since these authors used a moistened cotton swab while, in this study, the cornea was scraped with a proper spatula.

In this work, five dogs with corneal ulcer also presented KCS, which causes desiccation and inflammation of the conjunctiva and cornea. Tear deficiency decreases nutritional factors, growth factors, and antibacterial enzymes (lactoferrin, lysozyme, peroxidase), which encourage the growth of bacteria (Kaswan and Fullard, 1993; Whitley, 2000). This could explain a higher incidence of positive cultures from the cornea of dogs with KCS (93\%) reported by Salisbury et al. (1995), even though they also used swabs for sampling collection.

Twelve breeds were represented in the present study. The most representative were poodle and pekinese (three animals each). From the three animals with bilateral corneal ulcer, one was a mixed breed and two were pekinese and all presented KCS. However, there was no significative difference between the breeds and the incidence of corneal ulcer.

The frequency of the corneal ulcer microorganisms found in this study is similar to previous studies related to different animals (Gerding Jr. and Kakoma, 1990; Kodikara et al., 1999). Gram-positive microorganisms $(80.7 \%)$ predominated over Gram-negative bacteria $(19.3 \%)$ and the genus Staphylococcus spp. was the most isolated $(45.2 \%)$. Similar results were found in healthy dogs in São Paulo (43.9\%) (Teixeira et al., 2002), from dogs with external eye diseases in Florida - USA (69.0\%) (Salisbury et al., 1995), and Illinois - USA $(39.3 \%)$ (Gerding et al., 1988). S. intermedius represented $35.5 \%$ of the isolates in this research. Gerding Jr. et al. (1988) reported that $S$. intermedius was also the most representative bacterial species, however, with only $17.3 \%$ of the isolates.

According to Gerding et al. (1988), the most effective antibiotics for Staphylococcus spp. were bacitracin, gentamicin and tobramycin; while chloramphenicol and erythromycin for Streptococcus spp.. However, data from the present study showed that erythromycin was not effective against the isolated Streptococcus spp.

Moore et al. (1995) considered chloramphenicol a less desirable initial choice to treat corneal ulcers since resistant Pseudomonas infections may develop soon after topical treatment is initiated. In addition, some strains of $P$. aeruginosa are resistant to gentamicin and close monitoring is really important when using this antibiotic (Moore et al., 1995). However, in this study there were no signs of $P$. aeruginosa resistance to chloramphenicol or gentamicin, probably due to a small number of samples or a less evident selective pressure.

The treatment for a corneal ulcer should be based on culture and antimicrobial susceptibility testing. However, very often the choice of an antimicrobial therapy has to be taken before obtaining results of the antimicrobial susceptibility tests. Therefore, knowledge of the most commonly isolated bacteria in the canine eye from a specific geographic area is important to provide the most efficacious antibiotic treatment. In this study, the results showed that $80.7 \%$ of the isolates were Gram positive cocci and Gram positive bacilli, and those species were sensitive to gentamicin, ciprofloxacin, chloramphenicol and tobramycin. Therefore, for those regions, they are the antimicrobials of choice when ulcerative keratitis is present.

\section{ACKNOWLEGMENTS}

The authors would like to acknowledge Professor André J. Monteiro from Departamento de Estatística e Matemática Aplicada at the UFC and Maria F.S. Teixeira, post-graduation student at UECE, for the collaboration given in the present work. 


\section{REFERENCES}

GELATT, K.N. Essentials of veterinary ophthalmology. 3.ed. Philadelphia: Lippincott Williams \& Wilkins, 2000. 595p.

GERDING Jr., P.A.; KAKOMA, I. Microbiology of the canine and feline eye. Vet. Clin. N. Am.: Small Anim. Pract., v.20, p.615$625,1990$.

GERDING, P.A.; McLAUGHLIN, S.A.; TROOP, M.W. Pathogenic bacteria and fungi associated with external diseases in dogs: 131 cases (1981-1986). J. Am. Vet. Med. Assoc., v.193, p.242-244, 1988.

KASWAN, R.L.; FULLARD, R.J. Components in normal dogs tears and tears from dogs treated with cyclosporine. In: Sjogren's syndrome: state of the art. New York: Kugler Publications, 1993. p.265-271.

KODIKARA, D.S.; SILVA, N.; MAKULOLUWA, C.A.B. et al. Bacterial and fungal pathogens isolated from corneal ulcerations in domestic elephants (Elephas maximus maximus). Vet. Ophthalmol., v.2, p.191-192, 1999.

KONEMAN, E. W.; ALLEN, S. S.; JANDA, W. $M$. et al. Diagnóstico microbiológico. 5.ed. Rio de Janeiro: Medsi Editora Médica e Científica, 2001.

MOORE, C.; COLLINS, B.K.; FALES, W.H. et al. Antimicrobial agents for treatment of infectious keratitis in horses. J. Am. Vet. Med. Assoc., v.207, p.855-861, 1995.

MOORE, C.P.; HELLER, N.; MAJORS, L.J. et al. Prevalence of ocular microorganisms in hospitalized and stabled horses. Am. J. Vet. Res., v.49, p.773-777, 1988.

PERFORMANCE standards for antimicrobial susceptibility testing. 9.ed. Pensylvania: National Committee for Clinical and Laboratory Standards, 1999. 104p.

SALISBURY, M.A.R.; KASWAN, R.L.; BROWN, J. Microorganisms isolated from the corneal surface before and during topical cyclosporine treatment in dogs with keratoconjuntivitis sicca. Am. J. Vet. Res., v.56, p.880-884, 1995.

SLATTER, D.H. Fundamentals of veterinary ophthalmology. 3.ed. Philadelphia: W.B. Saunders, 2001. 640p.

SUZUKI, K.; SAITO, J.; YANAI, R. et al. Cell interactions during corneal epithelial wound healing. Prog. Ret. Eye Res., v.22, p.113-133, 2003.

TEIXEIRA, A.L.; MAIA, F.B.N.; ALVARENGA, L.S. et al. Aerobic conjunctival flora of healthy dogs in São Paulo. In: ANNUAL MEETING OF THE AMERICAN COLLEGE OF VETERINARY OPHTHALMOLOGY, 32 ., 2002. Denver. Vet. Ophthalmol., v.5, p.296, 2002.

WHITLEY, R.D. Canine and feline primary ocular bacterial infections. Vet. Clin. N. Am.: Small Anim. Pract., v.30, p.1151-1167, 2000.

WHITLEY, R.D.; GILGER, B.C. Diseases of the canine cornea and sclera. In: GELATT, K.N. (Ed.). Veterinary ophthalmology. 3.ed. Maryland: Lippincott Williams \& Wilkins, 1999. p.635-673. 